\title{
Review
}

Metabolic Risk/Epidemiology

Diabetes Metab J 2021;45:482-491

https://doi.org/10.4093/dmj.2020.0277

pISSN 2233-6079 · eISSN 2233-6087

DIABET\&S \& METABOLISM JOURNAL

\section{Computed Tomography-Derived Myosteatosis and Metabolic Disorders}

\author{
Iva Miljkovic ${ }^{1}$, Chantal A. Vella ${ }^{2}$, Matthew Allison ${ }^{3}$ \\ ${ }^{1}$ Department of Epidemiology, Graduate School of Public Health, University of Pittsburgh, Pittsburgh, PA, \\ ${ }^{2}$ Department of Movement Sciences, College of Education, Health and Human Sciences, University of Idaho, Moscow, ID, \\ ${ }^{3}$ Department of Family Medicine and Public Health, School of Medicine, University of California San Diego, La Jolla, CA, USA
}

The role of ectopic adipose tissue infiltration into skeletal muscle (i.e., myosteatosis) for metabolic disorders has received considerable and increasing attention in the last 10 years. The purpose of this review was to evaluate and summarize existing studies focusing on computed tomography (CT)-derived measures of myosteatosis and metabolic disorders. There is consistent evidence that CT-derived myosteatosis contributes to dysglycemia, insulin resistance, type 2 diabetes mellitus, and inflammation, and, to some extent, dyslipidemia, independent of general obesity, visceral fat, and other relevant risk factors, suggesting that it may serve as a tool for metabolic risk prediction. Identification of which muscles should be examined, and the standardized CT protocols to be employed, are necessary to enhance the applicability of findings from epidemiologic studies of myosteatosis. Additional and longer longitudinal studies are necessary to confirm a role of myosteatosis in the development of type 2 diabetes mellitus, and examine these associations in a variety of muscles across multiple race/ethnic populations. Given the emerging role of myosteatosis in metabolic health, well-designed intervention studies are needed to investigate relevant lifestyle and pharmaceutical approaches.

Keywords: Adipose tissue; Diabetes mellitus, type 2; Dyslipidemias; Inflammation; Insulin resistance; Muscle, skeletal

\section{INTRODUCTION: DEFINING SKELETAL MUSCLE FAT INFILTRATION}

Higher lipid accumulation around and within organs that normally contain only small amounts of adipose tissue (referred to as ectopic fat) can impair the normal physiologic function of those organs [1-3]. Ectopic adipose tissue infiltration in skeletal muscle (also known as myosteatosis) has emerged as a physiologically relevant fat depot, which may play a key role in the risk of metabolic abnormalities [4].

Myosteatosis quantification can be performed noninvasively using imaging devices, such as computed tomography (CT), magnetic resonance imaging, and quantitative ultrasound [5]. Advantages and disadvantages of imaging modalities in assessing myosteatosis have been recently described elsewhere [5].
Although there is no established gold standard to quantify myosteatosis [4,5], CT has been the most utilized as a research tool to investigate this fat depot, especially in large populationbased studies. CT can distinguish fat from muscle based on tissue attenuation, which is a function of tissue density and chemical composition. In this regard, the mean attenuation/ density of muscle measured by CT reflects the lipid content determined by biochemical and histological analysis [6]. In the literature, the most common range for classifying adipose tissue/myosteatosis is a Hounsfield units (HU) range from -190 to $-30 \mathrm{HU}$ [7]. On the other hand, there is some variability across studies in using a HU range to define muscle. Most usually start at either 0 or $29 \mathrm{HU}$ and extend to 100 [7]. A representation of adipose and muscle tissue areas of interest derived from abdominal CT scans is shown in Fig. 1.
Corresponding author: Matthew Allison (D) https://orcid.org/0000-0003-0777-8272 Department of Family Medicine and Public Health, School of Medicine, University of California San Diego, 9500 Gilman Drive, La Jolla, CA 92093, USA

E-mail: mallison@health.ucsd.edu.
This is an Open Access article distributed under the terms of the Creative Commons Attribution Non-Commercial License (https://creativecommons.org/licenses/by-nc/4.0/) which permits unrestricted non-commercial use, distribution, and reproduction in any medium, provided the original work is properly cited. 


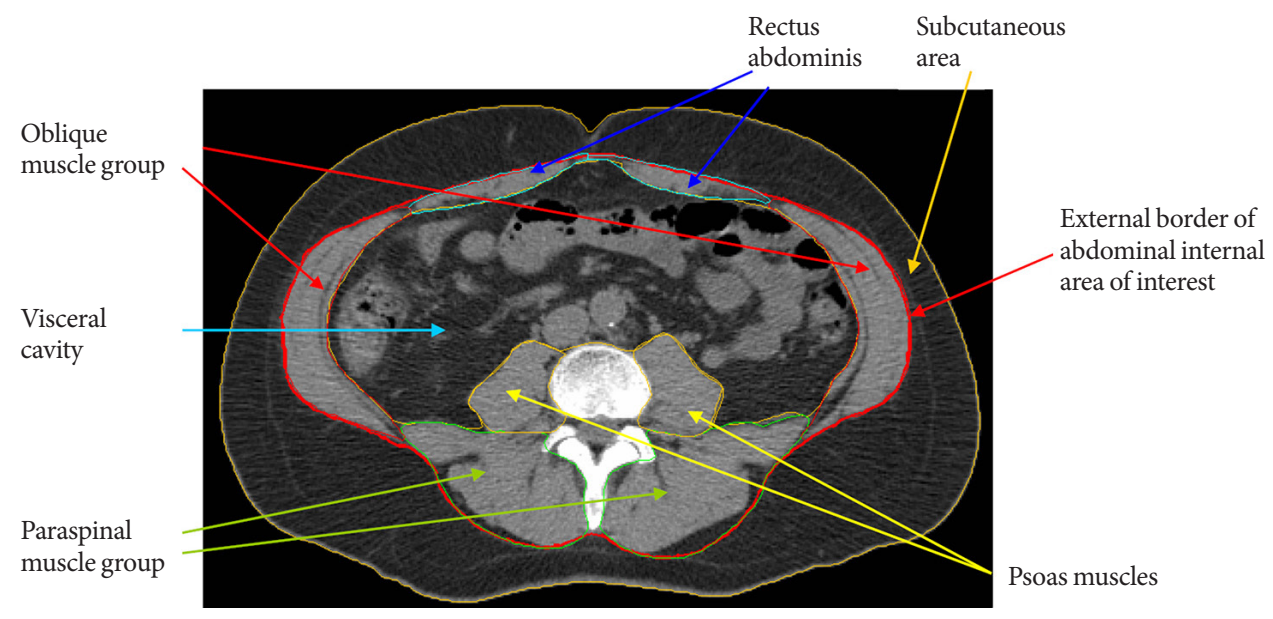

Fig. 1. Representation of areas of interest (adipose tissue and muscle measures) derived from abdominal computed tomography (CT) scans in the Multi-Ethnic Study of Atherosclerosis (MESA) cohort. The morphologically discrete tissues measured during CT image processing are: subcutaneous area which lies between the dermis and the fascia of the abdominal muscles; visceral cavity area with the internal organs; and abdominal skeletal muscles. The specific muscle groups denoted by psoas muscles (yellow arrows), paraspinal muscles (green arrows), oblique muscles (red arrows), and rectus abdominis muscles (blue arrows). Adipose tissue is identified as being between -190 and -30 Hounsfield units (HU). Lean tissue is identified as being between 0 and 100 HU. Inter-muscular adipose tissue is the sum of the pixels within a given muscle fascia. Intramuscular fat is computed as the mean of the pixel $\mathrm{HU}$ values between 0 and 99 for a given muscle group, with a higher mean density value for muscle indicating less intramuscular fat.

Using CT imaging, two fat depots are identified within skeletal muscle with possible varying functions [8,9]: (1) intermuscular adipose tissue (IMAT) is "marbled" skeletal muscle within the corresponding fascia and between muscle groups, while (2) intra-muscular adipose tissue defined as fat within the muscle fibers. The former can be characterized as volume and/or density of the adipose tissue, while the latter is represented by muscle density (i.e., lower density is indicative of greater intra-muscular adipose tissue content) [10]. It is important to emphasize that the variations in fat infiltration nomenclature makes comparison across studies difficult. Moreover, inconsistencies in image acquisition protocols across technologies, including muscle groups and regions measured, have substantial effects on analysis protocols and results interpretation. Upon this background, the aim of this review was to evaluate and summarize existing studies focusing on the CTderived myosteatosis and metabolic disorders.

\section{MYOSTEATOSIS AND INSULIN RESISTANCE AND TYPE 2 DIABETES MELLITUS}

As a major site of insulin-stimulated glucose disposal, skeletal muscle plays a key role in the control of blood glucose levels, as well as type 2 diabetes mellitus (T2DM) risk [11,12]. In the past 17 years, there were a number of studies focusing on CTmeasured IMAT and/or muscle density, and T2DM. All were primarily cross-sectional in design. Table 1 summarizes the described studies provided next. Goodpaster et al. [13] were the first to report in 2003 a positive association between CTmeasured thigh IMAT and T2DM among 2,964 White and African-American participants of the Health, Aging and Body Composition Study (Health ABC Study), aged 70 years and older. Around the same time, another study conducted among 75 obese nondiabetic Koreans, reported that thigh skeletal muscle density was associated with insulin resistance, as estimated by homeostasis model assessment for insulin resistance (HOMA-IR); an association which persisted even after adjusting for visceral adipose tissue (VAT) [14]. A few years later, the Tobago Health Study, conducted in 1,249 African-Caribbean men aged 40 years and older, reported that CT-measured calf IMAT was positively associated with prevalent T2DM, even in a subset of non-obese men [15]. The same study also tested the association between tertiles of IMAT and fasting serum glucose levels, stratified by family history of T2DM. The positive association between IMAT and fasting serum glucose was stronger in men who had a family history of T2DM than in 
Table 1. Summary of studies on myosteatosis and metabolic disorders

\begin{tabular}{|c|c|c|c|c|c|}
\hline Reference & Design & Sample & Exposure(s) & $\begin{array}{c}\text { Relevant } \\
\text { outcome(s) }\end{array}$ & $\begin{array}{l}\text { Significant associations (+) } \\
\text { positive; (-) inverse; (n) null }\end{array}$ \\
\hline \multicolumn{6}{|l|}{ Insulin resistance and T2DM } \\
\hline $\begin{array}{l}\text { Goodpaster et al. (2003) } \\
\text { [13] }\end{array}$ & Cross-sectional & $\begin{array}{l}1,447 \text { Men } / 1,517 \text { women } \\
\text { Mean age } 74 \text { years } \\
\text { Black and White } \\
\text { Health ABC Study }\end{array}$ & Thigh IMAT & $\begin{array}{l}\text { Glucose } \\
\text { Insulin } \\
\text { T2DM }\end{array}$ & $\begin{array}{l}\text { Glucose (n) } \\
\text { Insulin (+) in normal weight } \\
\text { Insulin (n) in overweight and obese } \\
\text { T2DM (+) }\end{array}$ \\
\hline Kim et al. (2003) [14] & Cross-sectional & $\begin{array}{l}23 \mathrm{Men} / 52 \text { women } \\
\text { Mean age } 41.9 \text { years } \\
\text { Obese, Korean }\end{array}$ & $\begin{array}{l}\text { Thigh low-density } \\
\text { muscle }\end{array}$ & HOMA-IR & HOMA-IR (+) \\
\hline $\begin{array}{l}\text { Miljkovic-Gacic et al. } \\
\text { (2008) [15] }\end{array}$ & Cross-sectional & $\begin{array}{l}1249 \text { African-Caribbean men } \\
\text { Mean age } 59 \text { years } \\
\text { Age range } 40-91 \text { years } \\
\text { Tobago Health Study }\end{array}$ & Calf IMAT & Prevalent T2DM & Prevalent T2DM (+) \\
\hline $\begin{array}{l}\text { Miljkovic et al. (2013) } \\
\text { [17] }\end{array}$ & Cross-sectional & $\begin{array}{l}393 \text { Men } \\
\text { Mean age } 74 \text { years } \\
\text { White } \\
\text { Osteoporotic Fractures in Men } \\
\text { Study }\end{array}$ & $\begin{array}{l}\text { Abdominal IMAT } \\
\text { (total abdominal, } \\
\text { psoas, paraspi- } \\
\text { nal) }\end{array}$ & $\begin{array}{l}\text { Glucose } \\
\text { Insulin } \\
\text { HOMA-IR }\end{array}$ & $\begin{array}{l}\text { Total abdominal and psoas IMAT } \\
\text { associated with: } \\
\text { Glucose }(+) \\
\text { Insulin (+) } \\
\text { HOMA-IR (+) }\end{array}$ \\
\hline $\begin{array}{l}\text { Granados et al. (2019) } \\
\text { [18] }\end{array}$ & Cross-sectional & $\begin{array}{l}\text { 3,170 Men and women } \\
\text { Age range } 43-55 \text { years } \\
\text { Black and White } \\
\text { CARDIA Study }\end{array}$ & Abdominal IMAT & $\begin{array}{l}\text { Prediabetes } \\
\text { T2DM }\end{array}$ & $\begin{array}{l}\text { Prediabetes }(+) \\
\text { T2DM }(+)\end{array}$ \\
\hline $\begin{array}{l}\text { Miljkovic et al. (2020) } \\
\text { [20] }\end{array}$ & Cross-sectional & $\begin{array}{l}718 \text { African-Caribbean men } \\
\text { Mean age } 64 \text { years } \\
\text { Tobago Health Study }\end{array}$ & Calf muscle density & $\mathrm{T} 2 \mathrm{DM}$ & T2DM (-) in non-obese men only \\
\hline Flowers et al. (2019) [22] & Cross-sectional & $\begin{array}{l}\text { 2,615 Men and women } \\
\text { Mean age } 61 \text { years } \\
\text { South Asian, White, Chinese } \\
\text { American, Black, and Hispanic } \\
\text { MASALA and MESA }\end{array}$ & Abdominal IMAT & $\begin{array}{l}\text { Impaired fasting } \\
\text { glucose } \\
\text { T2DM }\end{array}$ & $\begin{array}{l}\text { Impaired fasting glucose (+) in White } \\
\text { and HispanicImpaired fasting } \\
\text { glucose (n) in South Asian-, } \\
\text { Chinese- and African-American } \\
\text { T2DM (+) in White and Hispanic } \\
\text { T2DM (-) in African American } \\
\text { T2DM (n) in South Asian- and } \\
\text { Chinese-American }\end{array}$ \\
\hline $\begin{array}{l}\text { Therkelsen et al. (2013) } \\
\text { [19] }\end{array}$ & Cross-sectional & $\begin{array}{l}1,466 \mathrm{Men} / 1,479 \text { women } \\
\text { Mean age } 51 \text { years } \\
\text { White } \\
\text { Framingham Heart Study }\end{array}$ & $\begin{array}{l}\text { Paraspinous } \\
\text { muscle density }\end{array}$ & $\begin{array}{l}\text { Glucose } \\
\text { HOMA-IR } \\
\text { Impaired fasting } \\
\text { glucose } \\
\text { T2DM }\end{array}$ & $\begin{array}{l}\text { Glucose (-) } \\
\text { HOMA-IR (-) } \\
\text { Impaired fasting glucose (-) in women } \\
\text { Impaired fasting glucose (n) in men } \\
\text { T2DM (-) }\end{array}$ \\
\hline $\begin{array}{l}\text { Miljkovic et al. (2016) } \\
\text { [23] }\end{array}$ & Longitudinal & $\begin{array}{l}\text { 1,515 African-Caribbean men } \\
\text { Mean age } 57 \text { years }\end{array}$ & Calf IMAT & Incident T2DM & Incident T2DM (+) \\
\hline Tanaka et al. (2020) [24] & Longitudinal & $\begin{array}{l}621 \text { Japanese men and women } \\
\text { without diabetes } \\
\text { Middle-aged } \\
\text { Nishimura Health Survey }\end{array}$ & $\begin{array}{l}\text { Abdominal muscle } \\
\text { density } \\
\text { Abdominal low-at- } \\
\text { tenuation muscle }\end{array}$ & Incident T2DM & $\begin{array}{l}\text { Muscle density associated with } \\
\text { incident T2DM (-) } \\
\text { Low attenuation muscle associated } \\
\text { with incident T2DM }(+)\end{array}$ \\
\hline \multicolumn{6}{|l|}{ Lipids } \\
\hline $\begin{array}{l}\text { Miljkovic et al. (2013) } \\
\text { [34] }\end{array}$ & Cross-sectional & $\begin{array}{l}\text { 1,821 African-Caribbean men } \\
\text { Mean age } 59 \text { years } \\
\text { Tobago Health Study }\end{array}$ & $\begin{array}{l}\text { Calf IMAT } \\
\text { Calf muscle density }\end{array}$ & $\begin{array}{l}\text { Triglycerides } \\
\text { LDL-C } \\
\text { HDL-C }\end{array}$ & $\begin{array}{l}\text { Triglycerides (n) and HDL-C (n) } \\
\text { Muscle density associated with LDL-C } \\
(+)\end{array}$ \\
\hline $\begin{array}{l}\text { Durheim et al. (2008) } \\
\text { [35] }\end{array}$ & Longitudinal & $\begin{array}{l}40 \text { Men } / 33 \text { women } \\
\text { Age range } 50-65 \text { years } \\
\text { White and Black }\end{array}$ & Thigh IMAT & $\begin{array}{l}\text { LDL-C particle } \\
\text { size } \\
\text { HDL-C particle } \\
\text { size }\end{array}$ & $\begin{array}{l}\text { Reduction in thigh IMAT associated } \\
\text { with shifts in HDL-C and LDL-C to } \\
\text { larger particles in men only }\end{array}$ \\
\hline
\end{tabular}

(Continued to the next page) 
Table 1. Continued

\begin{tabular}{|c|c|c|c|c|c|}
\hline Reference & Design & Sample & Exposure(s) & $\begin{array}{c}\text { Relevant } \\
\text { outcome(s) }\end{array}$ & $\begin{array}{l}\text { Significant associations }(+) \\
\text { positive; }(-) \text { inverse; (n) null }\end{array}$ \\
\hline Vella et al. (2020) [36] & Cross-sectional & $\begin{array}{l}928 \text { Men } / 940 \text { women } \\
\text { Mean age } 65 \text { years } \\
\text { White, Chinese, Black, Hispanic } \\
\text { MESA }\end{array}$ & $\begin{array}{l}\text { Abdominal muscle } \\
\text { density (total } \\
\text { abdominal, } \\
\text { stability and } \\
\text { locomotor) }\end{array}$ & $\begin{array}{l}\text { Triglycerides } \\
\text { LDL-C } \\
\text { VLDL cholesterol } \\
\text { HDL-C } \\
\text { Total cholesterol }\end{array}$ & $\begin{array}{l}\text { Triglycerides (n) } \\
\text { LDL-C (n) } \\
\text { Total abdominal muscle density } \\
\text { associated with total cholesterol (+) } \\
\text { Locomotor muscle density associated } \\
\text { with VLDL (+), HDL (-), and total } \\
(+) \text { cholesterol }\end{array}$ \\
\hline $\begin{array}{l}\text { Mesinovic et al. (2019) } \\
\text { [37] }\end{array}$ & Cross-sectional & $\begin{array}{l}84 \text { Overweight and obese men } \\
\text { and women } \\
\text { Age } \geq 50 \text { years }\end{array}$ & $\begin{array}{l}\text { Forearm muscle } \\
\text { density } \\
\text { Calf muscle density }\end{array}$ & $\begin{array}{l}\text { Triglycerides } \\
\text { HDL-C }\end{array}$ & $\begin{array}{l}\text { Triglycerides (n) } \\
\text { HDL-C (n) }\end{array}$ \\
\hline \multicolumn{6}{|l|}{ Inflammation } \\
\hline $\begin{array}{l}\text { Miljkovic et al. (2011) } \\
\text { [38] }\end{array}$ & Cross-sectional & $\begin{array}{l}187 \mathrm{Men} / 284 \text { women } \\
\text { Mean age } 43 \text { years } \\
\text { Age range } 18-103 \text { years African- } \\
\text { Caribbean } \\
\text { Tobago Family Health Study }\end{array}$ & Calf muscle density & $\begin{array}{l}\text { CRP } \\
\text { IL-6 } \\
\text { TNF- } \alpha\end{array}$ & $\begin{array}{l}\operatorname{CRP}(-) \\
\operatorname{IL6}(\mathrm{n}) \\
\operatorname{TNF}(\mathrm{n})\end{array}$ \\
\hline $\begin{array}{l}\text { Van Hollebeke et al. } \\
\text { (2018) [39] }\end{array}$ & Cross-sectional & $\begin{array}{l}\text { 1,000 Men/961 women } \\
\text { Mean age } 65 \text { years } \\
\text { Range } 46-88 \text { years } \\
\text { White, Chinese, Black, Hispanic } \\
\text { MESA }\end{array}$ & $\begin{array}{l}\text { Abdominal muscle } \\
\text { density (total } \\
\text { abdominal, } \\
\text { stability, and } \\
\text { locomotor) }\end{array}$ & $\begin{array}{l}\text { CRP } \\
\text { IL-6 } \\
\text { TNF- } \alpha \\
\text { Resistin }\end{array}$ & $\begin{array}{l}\operatorname{CRP}(-) \\
\operatorname{IL}-6(-) \\
\text { TNF (n) } \\
\text { Resistin (-) }\end{array}$ \\
\hline Vella et al. (2018) [40] & Cross-sectional & $\begin{array}{l}983 \text { Men/961 women } \\
\text { Mean age } 65 \text { years } \\
\text { White, Chinese, Black, Hispanic } \\
\text { MESA }\end{array}$ & $\begin{array}{l}\text { Abdominal muscle } \\
\text { density (total } \\
\text { abdominal, } \\
\text { stability, and } \\
\text { locomotor) }\end{array}$ & $\begin{array}{l}\text { Adiponectin } \\
\text { Leptin }\end{array}$ & $\begin{array}{l}\text { Adiponectin (-) } \\
\text { Leptin (+) }\end{array}$ \\
\hline Vella et al. (2018) [41] & Cross-sectional & $\begin{array}{l}947 \text { Men/950 women } \\
\text { Mean age } 65 \text { years } \\
\text { White, Chinese, Black, Hispanic } \\
\text { MESA }\end{array}$ & $\begin{array}{l}\text { Total abdominal } \\
\text { muscle IMAT }\end{array}$ & $\begin{array}{l}\text { CRP } \\
\text { IL-6 } \\
\text { Adiponectin } \\
\text { Leptin } \\
\text { Resistin }\end{array}$ & $\begin{array}{l}\text { CRP (+) } \\
\text { IL-6 (+) } \\
\text { Leptin (+) } \\
\text { Adiponectin (-) } \\
\text { Resistin (n) }\end{array}$ \\
\hline Beasley et al. (2009) [42] & Cross-sectional & $\begin{array}{l}1,302 \text { Men/1,349 women } \\
\text { Age range } 70-79 \text { years } \\
\text { Black and White } \\
\text { Health ABC Study }\end{array}$ & Thigh IMAT & $\begin{array}{l}\text { CRP } \\
\text { IL-6 } \\
\text { TNF- } \alpha\end{array}$ & $\begin{array}{l}\text { CRP }(+) \\
\text { IL-6 (+) } \\
\text { TNF- } \alpha(+) \text { in women } \\
\text { TNF- } \alpha(n) \text { in men }\end{array}$ \\
\hline
\end{tabular}

T2DM, type 2 diabetes mellitus; Health ABC, Health Aging and Body Composition; IMAT, intermuscular adipose tissue; HOMA-IR, homeostasis model assessment for insulin resistance; CARDIA, Coronary Artery Risk Development in Young Adults; MASALA, Mediators of Atherosclorisis in South Asians Living in America; MESA, Multi-Ethnic Study of Atherosclerosis; LDL-C, low-density lipoprotein cholesterol; VLDL, very low-density lipoprotein; HDL-C, high-density lipoprotein cholesterol; CRP, C-reactive protein; IL-6, interleukin-6; TNF- $\alpha$, tumor necrosis factor alpha.

those without such history $(P<0.02$ for interaction after adjustment for age, height, total body fat, and total muscle area) suggesting that the association between IMAT and T2DM might be modified by a family history of T2DM [15].

These early studies prompted speculation by some researchers that myosteatosis is just a marker of metabolic dysfunction caused by VAT [16]. Thus, in the last 10 years, several well-designed, large, epidemiologic studies were able to test if the associations between myosteatosis and T2DM were independent of VAT. The majority of these newer studies have consistently reported that CT-measured IMAT $[17,18]$ and muscle density $[19,20]$ are associated with prevalent T2DM, independent of VAT, suggesting that metabolic impairments associated with increased myosteatosis are not simply due to increased VAT. For instance, the Osteoporotic Fractures in Men (MrOS) Study [17], among 393 nondiabetic elderly White men, found total abdominal IMAT and psoas IMAT to be positively associated with fasting HOMA-IR, independent of VAT. Similarly, the 
Coronary Artery Risk Development in Young Adults (CARDIA) Study [18], among 3,170 African-American and White participants aged 43 to 55 years, reported that total abdominal IMAT was positively associated with prevalence of T2DM, even after adjustment for VAT. Moreover, the Tobago Health Study [20], among 718 African-Caribbean men aged 40 years and older, reported that a lower muscle density in the calf was associated with greater prevalence of T2DM among non-obese men, independent of VAT, and other relevant ectopic fat depots, such as hepatic and pericardial adiposity. Notably, muscle density was not associated with T2DM among obese men in this cohort of African-Caribbeans.

The aforementioned findings suggest that myosteatosis may be relevant to T2DM risk among non-obese African-ancestry men, and might, in part, explain the "lean diabetes phenomenon", which is particularly prevalent among the United States African-American and other non-White men [21]. However, some recent studies, such as among 2,615 individuals from the Multi-Ethnic Study of Atherosclerosis (MESA) and the Mediators of Atherosclerosis in South Asians Living in America (MASALA) [22] found an association between abdominal IMAT with impaired fasting glucose and T2DM among Whites and Hispanic Americans, but not among South Asian Americans, Chinese Americans, and African Americans, while in African Americans abdominal IMAT was paradoxically inversely associated with T2DM. Also, the Framingham Heart Study [19], among 2,945 White men and women with a mean age of 50 years, reported that abdominal paraspinal muscle density was inversely associated with fasting glucose and HOMA-IR among women only, though importantly these associations were significantly attenuated by VAT.

Thus far, only two longitudinal studies have reported evidence on the relationship between myosteatosis and incident T2DM. The Tobago Health Study [23] was conducted among
1212 non-diabetic African-Caribbean men aged 40 years and older who were followed for 6 years. Increased IMAT during follow-up was associated with an increased incident risk of T2DM independent of general and central adiposity and lifestyle risk factors [23]. The second study [24] evaluated 621 middle-aged Japanese non-diabetic individuals from a cohort of employees undergoing annual physical examinations, who were followed for 3 years. The authors reported that total abdominal muscle density was associated with a higher risk for incident T2DM, independent of VAT, and relevant lifestyle factors. Clearly, further large and longer epidemiologic studies are needed to explore the relationship between myosteatosis and incident T2DM among other ethnic/race populations, and across wide age ranges and sex.

Despite these suggestive associations, causal relationships between myosteatosis and both insulin resistance and T2DM need to be established in mechanistic studies. That is, it remains to be clarified if myosteatosis is a marker or mediator of insulin resistance as glucose disorders are hypothesized to be bi-directionally associated with myosteatosis. The potential mechanisms underlying metabolic consequences of CT-derived myosteatosis are illustrated in Fig. 2. Ectopic fat is composed primarily of white adipose tissue, which shows reduced capillarization and cellularity [25-27]. Some groups accordingly hypothesized that increased accumulation of IMAT may impair nutritive blood flow to muscles and lead to impaired insulin action and insulin diffusion capacity [28]. Although the mechanisms of the reduction of skeletal muscle blood flow due to increased accumulation of adipose tissue are incompletely understood, they may involve structural changes in the skeletal muscle microvasculature $[29,30]$. With its unique position and close proximity to the muscle fiber, IMAT may also impact muscle metabolism and insulin sensitivity by impairment of myokine secretion and/or by increased production of

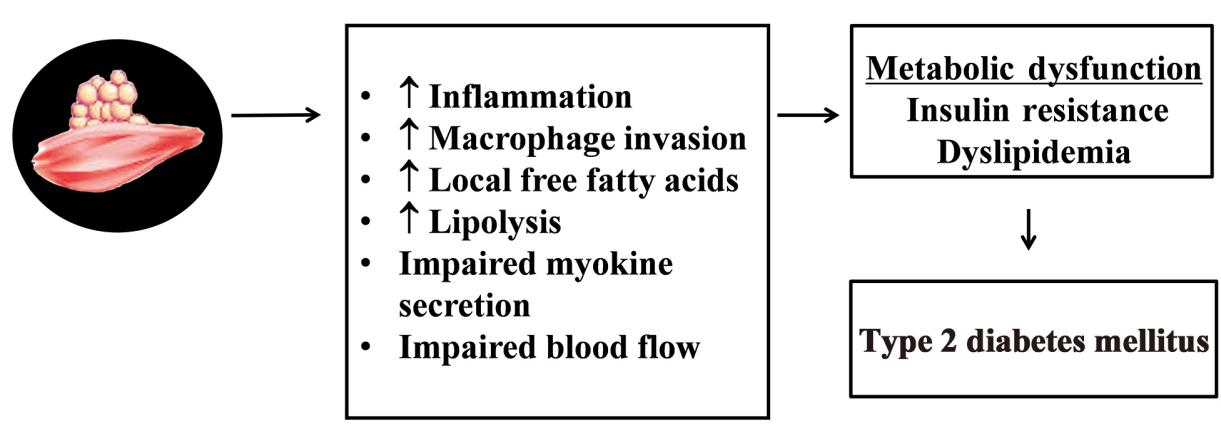

Fig. 2. Potential mechanisms underlying metabolic consequences of computed tomography-derived myosteatosis. 
pro-inflammatory adipokines and/or reduced production of anti-inflammatory adipokines [31,32]. For example, it was recently reported that IMAT is related to skeletal muscle secreted myostatin, both in the untrained state and in response to exercise training [33]. More recent findings indicate that factors secreted from abdominal IMAT may directly modulate muscle insulin sensitivity, possibly via secretion of inflammatory adipokines and with increased macrophage invasion, as well as increased local free fatty acids [32]. These findings provide further direct support that myosteatosis may be an important biologic regulator of skeletal muscle insulin sensitivity and could be a novel therapeutic target for skeletal muscle insulin resistance. Still, more work is needed on understanding the mechanisms linking myosteatosis with insulin resistance and T2DM.

\section{MYOSTEATOSIS AND LIPID AND LIPOPROTEIN LEVELS}

Although the associations between obesity and serum lipids and lipoproteins are well established, less is known about the impact of ectopic adipose tissue on these biomarkers of cardiometabolic disease. Few studies have investigated the associations between CT-derived skeletal muscle density and both lipid and lipoprotein levels. These are briefly summarized in Table 1. Miljkovic et al. [34] studied 1,821 men from the Tobago Health Study and reported a strong, positive association between calf muscle density and low-density lipoprotein cholesterol (LDL-C), independent of age, total body fat measured by dual-energy x-ray absorptiometry, HOMA-IR, and lifestyle factors. They also reported age-adjusted calf muscle density was inversely associated with high-density lipoprotein cholesterol (HDL-C), but this association was attenuated after adjustment for other covariates. No associations were found with triglycerides. The authors suggested that the positive association between calf muscle density and LDL-C may be driven by the less dense more favorable large LDL particle subfraction. Support for this hypothesis comes from a longitudinal study that reported exercise-induced reductions in thigh IMAT were independently associated with a shift in HDL-C and LDL-C to larger, less atherogenic lipoprotein particles in sedentary dyslipidemic men but not women [35]. To our knowledge, this is the only longitudinal study to date investigating change in CTderived IMAT with lipids and lipoproteins and focused only on particle size.

In contrast, Vella et al. [36] studied a slightly older cohort of
1,868 men and women from the MESA and reported a strong, positive and independent association between total abdominal muscle density and total cholesterol, but not LDL-C, HDL-C, or triglycerides. Additionally, locomotor muscle density was positively and independently associated with total cholesterol and very low-density lipoprotein cholesterol, whereas stability muscle density was not associated with any of the lipids or lipoproteins measured. Finally, and contrary to the above findings, Mesinovic et al. [37] reported no significant associations between forearm and calf muscle density with triglycerides or HDL-C in a small sample of community dwelling older adults from Australia $(n=84)$.

Together these findings suggest that the impact of adipose tissue infiltration of skeletal muscle on lipid and lipoprotein levels may vary by muscle type, morphology, and/or function. However, more research is needed to better understand the role of myosteatosis on lipid and lipoprotein levels.

\section{MYOSTEATOSIS AND INFLAMMATION}

Prior research has consistently shown that skeletal muscle density is associated with biomarkers of inflammation in middleaged and older adults, although there may be differences across muscle groups (Table 1). In a cohort of 471 men and women of African ancestry, and after adjustment for relevant covariates including demographics, skeletal muscle area, current anti-inflammatory medication use, Miljkovic et al. [38] reported calf muscle density was inversely correlated with C-reactive protein (CRP), but not interleukin-6 (IL-6) or tumor necrosis factoralpha (TNF- $\alpha$ ). Using data from the MESA, Van Hollebeke et al. [39] showed that total abdominal, locomotor and stability muscle density, were inversely associated with CRP, IL-6, and resistin. However, the associations with CRP were attenuated in all muscle groups after adjustment for abdominal subcutaneous and VAT. This is inconsistent with the findings from Miljkovic et al. [38] but may be due to the depot of fat that was controlled for, which differed across studies.

Vella et al. [40] found that higher levels of total abdominal, stability and locomotor muscle density were associated with significantly lower levels of adiponectin and higher levels of leptin, independent of relevant covariates, including subcutaneous and VAT, cardiovascular disease risk factors, and other inflammatory markers. In the fully adjusted model, every 5.5 $\mathrm{HU}$ increase in total abdominal muscle density was associated with a $31 \%$ lower adiponectin and $6.7 \%$ higher leptin. 
Similarly, a higher abdominal IMAT was shown to be independently associated with higher levels of IL-6, CRP, and leptin, and lower levels of adiponectin in MESA [41]. Although these associations were independent of relevant covariates, including cardiovascular disease risk factors, physical activity, sedentary behavior, and other markers of inflammation, they were largely attenuated to non-significance by controlling for subcutaneous and VAT. These findings, together with the findings of Van Hollebeke et al. [39], suggest that the association between muscle density and inflammation is likely mediated by central obesity. Moreover, data from the Health $A B C$ Study reported that thigh IMAT was significantly and positively associated with IL-6, CRP, and TNF- $\alpha$ in 2,651 older adults, but the associations differed by sex and race [42]. With adjustment for BMI, the associations between thigh IMAT and IL-6 in all men remained significant, whereas the association with CRP was attenuated in White men but not African-American men. In contrast, thigh IMAT was significantly associated with IL-6, CRP, and TNF- $\alpha$ in White women after adjustment for BMI, whereas only IL-6 remained significant in African American women.

Collectively, the results presented above suggest that adipose tissue infiltration of skeletal muscle may contribute to the chronic inflammation associated with obesity and increased risk of cardiometabolic disease. Improvements in muscle density may have positive impacts on chronic inflammation and, in turn, may reduce the risk of cardiometabolic disease.

\section{DIFFERENCES IN ASSOCIATIONS BY SEX AND RACE/ETHNICITY}

Despite no differences in the rates of age-related increases in myosteatosis $[43,44]$, prior studies have shown that women tend to have higher levels of CT-derived myosteatosis than men [19,43-47]. Similarly, African ancestry individuals may have higher levels of myosteatosis than non-Hispanic Whites [48-50], including IMAT in the thigh [42]. In general, little is known about myosteatosis in other race/ethnic groups, particularly among adult individuals. Eastwood et al. [51] found that differences in CT-derived myosteatosis between South Asian Indian and White adults disappear when adjusted for total body fat. Future studies should better define the role of race and ethnicity in accumulation of myosteatosis.

Some of the aforementioned studies tested for significant differences in the associations by sex and race/ethnicity. In general, there were few significant tests for interaction. Specifically, and from the MESA [52], there were significant interactions of sedentary behavior with race/ethnicity for total abdominal muscle density $(P=0.02)$, as well as stability muscle density $(P=0.02)$, with the associations between sedentary behavior and muscle density in Hispanics being significantly different than non-Hispanic Whites (referent group). That is, the slope of the non-linear, quadratic association was flatter (i.e., "weaker") for non-Hispanic Whites, but with a similar inflection point (32.1 vs. 34.6 metabolic equivalent-hours/week, respectively). Similarly, results from the Health ABC Study suggest that the associations between thigh muscle IMAT and different measures of inflammation (i.e., IL-6, CRP, and TNF- $\alpha$ ) are significantly smaller in African-American women, compared to White women [42]. On the other hand, there were no significant differences by sex or race/ethnicity for the associations between (1) IMAT and muscle density with adiponectin, leptin, IL-6, CRP, and resistin [41]; (2) muscle density with cholesterol, HDL-C, LDL-C, triglycerides and glucose [36]; (3) muscle density with coronary artery calcium [53]; and (4) muscle density with mortality [54].

\section{SUMMARY AND FUTURE RESEARCH}

Consistent evidence of an association of myosteatosis with metabolic disorders suggest that CT-derived measures of myosteatosis may be a very relevant contributor to metabolic risk prediction. Therefore, future interventions aimed at preventing and/or decreasing myosteatosis may lead to novel strategies to prevent metabolic disorders. Although it is still unclear which lifestyle and/or pharmacologic interventions may affect myosteatosis levels significantly, emerging evidence from controlled experimental studies and smaller studies with self-reported data suggest that physical activity may be central to decreasing myosteatosis or preventing its accumulation [55-58]. Large epidemiologic studies examining objectively-measured types and intensities of physical activity in relation to myosteatosis are still lacking. The use of other lifestyle or pharmaceutical interventions, either separately or combined, to delay or reverse myosteatosis are still largely unexplored. Future large, well-designed, multidisciplinary intervention studies are needed to examine the combination of diet, physical activity, and pharmacologic interventions to reverse myosteatosis.

Many other questions remain to be answered. Though there are a few studies on specific muscle groups, the association be- 
tween myosteatosis and metabolic disorders might be unique for specific muscle groups. That is, the previous findings illustrate the importance of separately studying myosteatosis in specific abdominal muscle groups (psoas, paraspinal, rectus abdominus, oblique muscle), as well as in abdominal versus thigh versus calf muscles, but more studies are needed. In addition, the previous studies of myosteatosis indicate that a sexspecific approach may be necessary, as well as those including diverse race and ethnic populations. Future longitudinal and/ or mechanistic studies are needed to (1) better understand the physiologic pathways involved in sex and race/ethnic differences in association of myosteatosis with metabolic disorders, (2) expand our understanding of mechanisms underlying the association of myosteatosis with metabolic disorders, and (3) determine if the mechanisms linking inter- and intramuscular fat with metabolic disease are different. Finally, identification of the standardized CT protocols to be employed, as well as the establishment of widely accepted HU cut-points, are necessary to enhance the applicability of findings from epidemiologic studies of myosteatosis.

\section{CONFLICTS OF INTEREST}

No potential conflict of interest relevant to this article was reported.

\section{ORCID}

Iva Miljkovic https://orcid.org/0000-0002-3155-9777

Matthew Allison https://orcid.org/0000-0003-0777-8272

\section{FUNDING}

None

\section{ACKNOWLEDGMENTS}

None

\section{REFERENCES}

1. Carobbio S, Rodriguez-Cuenca S, Vidal-Puig A. Origins of metabolic complications in obesity: ectopic fat accumulation. The importance of the qualitative aspect of lipotoxicity. Curr Opin Clin Nutr Metab Care 2011;14:520-6.
2. Morelli M, Gaggini M, Daniele G, Marraccini P, Sicari R, Gastaldelli A. Ectopic fat: the true culprit linking obesity and cardiovascular disease? Thromb Haemost 2013;110:651-60.

3. Rutkowski JM, Stern JH, Scherer PE. The cell biology of fat expansion. J Cell Biol 2015;208:501-12.

4. Correa-de-Araujo R, Harris-Love MO, Miljkovic I, Fragala MS, Anthony BW, Manini TM. The need for standardized assessment of muscle quality in skeletal muscle function deficit and other aging-related muscle dysfunctions: a symposium report. Front Physiol 2017;8:87.

5. Correa-de-Araujo R, Addison O, Miljkovic I, Goodpaster BH, Bergman BC, Clark RV, et al. Myosteatosis in the context of skeletal muscle function deficit: an interdisciplinary workshop at the national institute on aging. Front Physiol 2020;11:963.

6. Kelley DE, Slasky BS, Janosky J. Skeletal muscle density: effects of obesity and non-insulin-dependent diabetes mellitus. Am J Clin Nutr 1991;54:509-15.

7. Aubrey J, Esfandiari N, Baracos VE, Buteau FA, Frenette J, Putman CT, et al. Measurement of skeletal muscle radiation attenuation and basis of its biological variation. Acta Physiol (Oxf) 2014;210:489-97.

8. Vettor R, Milan G, Franzin C, Sanna M, De Coppi P, Rizzuto R, et al. The origin of intermuscular adipose tissue and its pathophysiological implications. Am J Physiol Endocrinol Metab 2009;297:E987-98.

9. Miljkovic I, Zmuda JM. Epidemiology of myosteatosis. Curr Opin Clin Nutr Metab Care 2010;13:260-4.

10. Goodpaster BH, Kelley DE, Thaete FL, He J, Ross R. Skeletal muscle attenuation determined by computed tomography is associated with skeletal muscle lipid content. J Appl Physiol (1985) 2000;89:104-10.

11. Trayhurn P, Drevon CA, Eckel J. Secreted proteins from adipose tissue and skeletal muscle: adipokines, myokines and adipose/muscle cross-talk. Arch Physiol Biochem 2011;117:47-56.

12. Samuel VT, Shulman GI. The pathogenesis of insulin resistance: integrating signaling pathways and substrate flux. J Clin Invest 2016;126:12-22.

13. Goodpaster BH, Krishnaswami S, Resnick H, Kelley DE, Haggerty $\mathrm{C}$, Harris TB, et al. Association between regional adipose tissue distribution and both type 2 diabetes and impaired glucose tolerance in elderly men and women. Diabetes Care 2003; 26:372-9.

14. Kim D, Nam S, Ahn C, Kim K, Yoon S, Kim J, et al. Correlation between midthigh low-density muscle and insulin resistance in obese nondiabetic patients in Korea. Diabetes Care 2003;26: 
1825-30.

15. Miljkovic-Gacic I, Gordon CL, Goodpaster BH, Bunker CH, Patrick AL, Kuller LH, et al. Adipose tissue infiltration in skeletal muscle: age patterns and association with diabetes among men of African ancestry. Am J Clin Nutr 2008;87:1590-5.

16. Elbein SC, Rasouli N. Intermuscular lipid: a marker of disordered fat partitioning or the consequence of obesity? Am J Clin Nutr 2008;87:1585-6.

17. Miljkovic I, Cauley JA, Wang PY, Holton KF, Lee CG, Sheu Y, et al. Abdominal myosteatosis is independently associated with hyperinsulinemia and insulin resistance among older men without diabetes. Obesity (Silver Spring) 2013;21:2118-25.

18. Granados A, Gebremariam A, Gidding SS, Terry JG, Carr JJ, Steffen LM, et al. Association of abdominal muscle composition with prediabetes and diabetes: the CARDIA study. Diabetes Obes Metab 2019;21:267-75.

19. Therkelsen KE, Pedley A, Speliotes EK, Massaro JM, Murabito J, Hoffmann U, et al. Intramuscular fat and associations with metabolic risk factors in the Framingham Heart Study. Arterioscler Thromb Vasc Biol 2013;33:863-70.

20. Miljkovic I, Kuipers AL, Cvejkus RK, Carr JJ, Terry JG, Thyagarajan $\mathrm{B}$, et al. Hepatic and skeletal muscle adiposity are associated with diabetes independent of visceral adiposity in nonobese African-Caribbean men. Metab Syndr Relat Disord 2020;18:275-83.

21. George AM, Jacob AG, Fogelfeld L. Lean diabetes mellitus: an emerging entity in the era of obesity. World J Diabetes 2015;6: 613-20.

22. Flowers E, Lin F, Kandula NR, Allison M, Carr JJ, Ding J, et al. Body composition and diabetes risk in South Asians: findings from the MASALA and MESA studies. Diabetes Care 2019;42: 946-53.

23. Miljkovic I, Kuipers AL, Cvejkus R, Bunker CH, Patrick AL, Gordon CL, et al. Myosteatosis increases with aging and is associated with incident diabetes in African ancestry men. Obesity (Silver Spring) 2016;24:476-82.

24. Tanaka M, Okada H, Hashimoto Y, Kumagai M, Nishimura H, Fukui M. Low-attenuation muscle is a predictor of diabetes mellitus: a population-based cohort study. Nutrition 2020;74: 110752 .

25. Camastra S, Vitali A, Anselmino M, Gastaldelli A, Bellini R, Berta R, et al. Muscle and adipose tissue morphology, insulin sensitivity and beta-cell function in diabetic and nondiabetic obese patients: effects of bariatric surgery. Sci Rep 2017;7:9007. 26. Ferrannini E, Iozzo P, Virtanen KA, Honka MJ, Bucci M, Nuu- tila P. Adipose tissue and skeletal muscle insulin-mediated glucose uptake in insulin resistance: role of blood flow and diabetes. Am J Clin Nutr 2018;108:749-58.

27. Pasarica M, Sereda OR, Redman LM, Albarado DC, Hymel DT, Roan LE, et al. Reduced adipose tissue oxygenation in human obesity: evidence for rarefaction, macrophage chemotaxis, and inflammation without an angiogenic response. Diabetes 2009;58:718-25.

28. Lee DE, Kehlenbrink S, Lee H, Hawkins M, Yudkin JS. Getting the message across: mechanisms of physiological cross talk by adipose tissue. Am J Physiol Endocrinol Metab 2009;296: E1210-29.

29. Gavin TP, Stallings HW 3rd, Zwetsloot KA, Westerkamp LM, Ryan NA, Moore RA, et al. Lower capillary density but no difference in VEGF expression in obese vs. lean young skeletal muscle in humans. J Appl Physiol (1985) 2005;98:315-21.

30. Sorop O, Olver TD, van de Wouw J, Heinonen I, van Duin RW, Duncker DJ, et al. The microcirculation: a key player in obesity-associated cardiovascular disease. Cardiovasc Res 2017;113: 1035-45.

31. Ahima RS, Park HK. Connecting myokines and metabolism. Endocrinol Metab (Seoul) 2015;30:235-45.

32. Sachs S, Zarini S, Kahn DE, Harrison KA, Perreault L, Phang T, et al. Intermuscular adipose tissue directly modulates skeletal muscle insulin sensitivity in humans. Am J Physiol Endocrinol Metab 2019;316:E866-79.

33. Konopka AR, Wolff CA, Suer MK, Harber MP. Relationship between intermuscular adipose tissue infiltration and myostatin before and after aerobic exercise training. Am J Physiol Regul Integr Comp Physiol 2018;315:R461-8.

34. Miljkovic I, Kuipers AL, Kuller LH, Sheu Y, Bunker CH, Patrick AL, et al. Skeletal muscle adiposity is associated with serum lipid and lipoprotein levels in Afro-Caribbean men. Obesity (Silver Spring) 2013;21:1900-7.

35. Durheim MT, Slentz CA, Bateman LA, Mabe SK, Kraus WE. Relationships between exercise-induced reductions in thigh intermuscular adipose tissue, changes in lipoprotein particle size, and visceral adiposity. Am J Physiol Endocrinol Metab 2008;295:E407-12.

36. Vella CA, Nelson MC, Unkart JT, Miljkovic I, Allison MA. Skeletal muscle area and density are associated with lipid and lipoprotein cholesterol levels: the Multi-Ethnic Study of Atherosclerosis. J Clin Lipidol 2020;14:143-53.

37. Mesinovic J, McMillan LB, Shore-Lorenti C, De Courten B, Ebeling PR, Scott D. Metabolic syndrome and its associations 
with components of sarcopenia in overweight and obese older adults. J Clin Med 2019;8:145.

38. Miljkovic I, Kuipers AL, Kammerer CM, Wang X, Bunker CH, Patrick AL, et al. Markers of inflammation are heritable and associated with subcutaneous and ectopic skeletal muscle adiposity in African ancestry families. Metab Syndr Relat Disord 2011;9:319-26.

39. Van Hollebeke RB, Cushman M, Schlueter EF, Allison MA. Abdominal muscle density is inversely related to adiposity inflammatory mediators. Med Sci Sports Exerc 2018;50:1495501.

40. Vella CA, Cushman M, Van Hollebeke RB, Allison MA. Associations of abdominal muscle area and radiodensity with adiponectin and leptin: the Multiethnic Study of Atherosclerosis. Obesity (Silver Spring) 2018;26:1234-41.

41. Vella CA, Allison MA. Associations of abdominal intermuscular adipose tissue and inflammation: the Multi-Ethnic Study of Atherosclerosis. Obes Res Clin Pract 2018;12:534-40.

42. Beasley LE, Koster A, Newman AB, Javaid MK, Ferrucci L, Kritchevsky SB, et al. Inflammation and race and gender differences in computerized tomography-measured adipose depots. Obesity (Silver Spring) 2009;17:1062-9.

43. Anderson DE, D’Agostino JM, Bruno AG, Demissie S, Kiel DP, Bouxsein ML. Variations of CT-based trunk muscle attenuation by age, sex, and specific muscle. J Gerontol A Biol Sci Med Sci 2013;68:317-23.

44. Xiao J, Caan BJ, Weltzien E, Cespedes Feliciano EM, Kroenke $\mathrm{CH}$, Meyerhardt JA, et al. Associations of pre-existing co-morbidities with skeletal muscle mass and radiodensity in patients with non-metastatic colorectal cancer. J Cachexia Sarcopenia Muscle 2018;9:654-63.

45. Goodpaster BH, Carlson CL, Visser M, Kelley DE, Scherzinger A, Harris TB, et al. Attenuation of skeletal muscle and strength in the elderly: the Health ABC Study. J Appl Physiol (1985) 2001;90:2157-65.

46. Hicks GE, Simonsick EM, Harris TB, Newman AB, Weiner DK, Nevitt MA, et al. Trunk muscle composition as a predictor of reduced functional capacity in the health, aging and body composition study: the moderating role of back pain. J Gerontol A Biol Sci Med Sci 2005;60:1420-4.

47. Ryan AS, Buscemi A, Forrester L, Hafer-Macko CE, Ivey FM. Atrophy and intramuscular fat in specific muscles of the thigh: associated weakness and hyperinsulinemia in stroke survivors. Neurorehabil Neural Repair 2011;25:865-72.
48. Gallagher D, Kuznia P, Heshka S, Albu J, Heymsfield SB, Goodpaster B, et al. Adipose tissue in muscle: a novel depot similar in size to visceral adipose tissue. Am J Clin Nutr 2005;81:903-10.

49. Miljkovic I, Cauley JA, Petit MA, Ensrud KE, Strotmeyer E, Sheu Y, et al. Greater adipose tissue infiltration in skeletal muscle among older men of African ancestry. J Clin Endocrinol Metab 2009;94:2735-42.

50. Delmonico MJ, Harris TB, Visser M, Park SW, Conroy MB, Velasquez-Mieyer P, et al. Longitudinal study of muscle strength, quality, and adipose tissue infiltration. Am J Clin Nutr 2009;90:1579-85.

51. Eastwood SV, Tillin T, Wright A, Mayet J, Godsland I, Forouhi NG, et al. Thigh fat and muscle each contribute to excess cardiometabolic risk in South Asians, independent of visceral adipose tissue. Obesity (Silver Spring) 2014;22:2071-9.

52. Vella CA, Michos ED, Sears DD, Cushman M, Van Hollebeke RB, Wiest MM, et al. Associations of sedentary behavior and abdominal muscle density: the Multi-Ethnic Study of Atherosclerosis. J Phys Act Health 2018;15:827-33.

53. Crawford MA, Criqui MH, Forbang N, Unkart JT, Allison MA, Larsen BA. Associations of abdominal muscle area and density with coronary artery calcium volume and density: the multiethnic study of atherosclerosis. Metabolism 2020;107:154230.

54. Larsen B, Bellettiere J, Allison M, McClelland RL, Miljkovic I, Vella CA, et al. Muscle area and density and risk of all-cause mortality: the Multi-Ethnic Study of Atherosclerosis. Metabolism 2020;111:154321.

55. Taaffe DR, Henwood TR, Nalls MA, Walker DG, Lang TF, Harris TB. Alterations in muscle attenuation following detraining and retraining in resistance-trained older adults. Gerontology 2009;55:217-23.

56. Prior SJ, Joseph LJ, Brandauer J, Katzel LI, Hagberg JM, Ryan AS. Reduction in midthigh low-density muscle with aerobic exercise training and weight loss impacts glucose tolerance in older men. J Clin Endocrinol Metab 2007;92:880-6.

57. Manini TM, Clark BC, Nalls MA, Goodpaster BH, PloutzSnyder LL, Harris TB. Reduced physical activity increases intermuscular adipose tissue in healthy young adults. Am J Clin Nutr 2007;85:377-84.

58. Goodpaster BH, Chomentowski P, Ward BK, Rossi A, Glynn NW, Delmonico MJ, et al. Effects of physical activity on strength and skeletal muscle fat infiltration in older adults: a randomized controlled trial. J Appl Physiol (1985) 2008;105:1498-503. 